\title{
Assessment of Trace Metals Concentration in Tree Barks as Indicator of Atmospheric Pollution within Ibadan City, South-West, Nigeria
}

\author{
Ikechukwu P. Ejidike ${ }^{1}$ and Percy C. Onianwa ${ }^{2}$ \\ ${ }^{1}$ Department of Chemistry, Faculty of Science and Agriculture, University of Fort Hare, PB X1314, Alice 5700, South Africa \\ ${ }^{2}$ Department of Chemistry, Faculty of Science, University of Ibadan, Ibadan, Nigeria
}

Correspondence should be addressed to Ikechukwu P. Ejidike; pejidike@ufh.ac.za

Received 23 July 2015; Revised 11 September 2015; Accepted 13 September 2015

Academic Editor: Miguel de la Guardia

Copyright (C) 2015 I. P. Ejidike and P. C. Onianwa. This is an open access article distributed under the Creative Commons Attribution License, which permits unrestricted use, distribution, and reproduction in any medium, provided the original work is properly cited.

\begin{abstract}
Tree bark species were randomly collected from 65 sites having different anthropogenic activities, such as industrial, high traffic commercial, residential high and residential low traffic volume areas of Ibadan City, Nigeria. Levels of $\mathrm{Cd}, \mathrm{Cu}, \mathrm{Pb}, \mathrm{Zn}, \mathrm{Co}$, and $\mathrm{Cr}$ of the dry-ashed bark samples were determined by AAS. The mean metal concentrations $\left(\mathrm{mg} \mathrm{kg}^{-1}\right)$ in samples from industrial zone were found as $\mathrm{Pb}: 3.67 \pm 1.97$, Cd: $0.10 \pm 0.07, \mathrm{Zn}: 30.96 \pm 32.05$, Cu: $7.29 \pm 5.17$, Co: $0.91 \pm 0.58$, and Cr: $2.61 \pm 1.84$. The trend of mean trace metal concentrations at high traffic commercial zone follows the order: $\mathrm{Zn}>\mathrm{Pb}>\mathrm{Cu}>\mathrm{Cr}>\mathrm{Co}>\mathrm{Cd}$. Residential high traffic and low traffic zones revealed the same trend as $\mathrm{Cd}<\mathrm{Co}<\mathrm{Cr}<\mathrm{Pb}<\mathrm{Cu}<\mathrm{Zn}$. Relatively strong positive correlation between the heavy metals at $\rho<0.05$, such as $\mathrm{Zn}$ versus $\mathrm{Cu}(r=0.79)$ and $\mathrm{Co}$ versus $\mathrm{Cu}(r=0.77)$, was observed. The results of the study suggest that tree bark samples could potentially serve as bioindicators for $\mathrm{Cu}, \mathrm{Pb}, \mathrm{Zn}, \mathrm{Cr}$, and possibly $\mathrm{Co}$ and $\mathrm{Cd}$. Furthermore, interspecies variation of heavy metal concentrations in plants barks is recommended.
\end{abstract}

\section{Introduction}

Air pollution was not perceived as a major problem in most countries until late 1960s and early 1970s; it was the global cooling forecast that captured public imagination in urban and industrialized areas [1]. In 2014, WHO released a report on air pollution, as the instigator of about 7 million people's death in 2012. These air contaminants are released into the ecosystem from immobile sources, such as power stations and other industries, and itinerant sources such as motorpowered vehicles, airplanes, and ships $[2,3]$. The release of these gaseous volatile organic and inorganic pollutants in the form of particulate matters with sizes $<10 \times 10^{-6} \mathrm{~m}$ [4] brings about steady deterioration of the air quality, giving rise to numerous cases of illness and even death, depletion of ozone layer, sulfurous and photochemical smog, acid rains, global warming, greenhouse effect, and physiological problem $[3,5]$. One of the natural components (inorganic pollutants) of the environment is heavy metals, due to the proliferation of industries, high immigrant rate, and increased urbanization $[6,7]$. Hence, they have been added to the ecosystem in large quantity, causing earth's atmosphere deterioration as it forms the life support of the planet $[8,9]$. According to Hashmi et al. [10] heavy metals have been found to play an imperative role in the biochemical, biological, chemical, catabolic, metabolic, and enzymatic reactions in living cells [11] but when present in excess amount, they affect plants and animals leading to various kinds of diseases due to their stumpy levels in voluminous environmental and biological samples $[12,13]$.

Biological materials are used to ascertain atmospheric trace metal concentrations [14-16]. The use of biomonitor, as it is easy to collect and cheap, has higher concentrations than air and rainwater for measuring the trace metal concentrations in the atmosphere $[17,18]$. Bioindicators of different entities are being used including vascular plants, mosses, woody plants, and lichens $[19,20]$. The use of vegetal 
biomonitoring to evaluate air quality has been investigated; one alternative is to characterize gradients of air pollution on a small scale by the use of biological monitors [21, 22]. In San Luis Potosi, one of the most industrially developed cities in Mexico, Beramendi-Orosco et al. [23] studied the correlations between $\mathrm{Zn}, \mathrm{Pb}$, and $\mathrm{Cu}$ in tree-ring sequences of Prosopis juliflora, a tree species native to arid environments. The results suggested that the smelter's emissions are dispersed to longer distances through the tall chimneys, thereby confirming Prosopis juliflora as a good bioindicator, thus providing information on the chronology and sources of heavy metal pollution in urban and industrial areas. Turkish red pine (Pinus brutia), a widespread evergreen tree, has been investigated by Baslar et al. [14] in Mediterranean and Aegean regions of Turkey. The barks were examined as biomonitor of $\mathrm{Zn}$ and $\mathrm{Mn}$ accumulation in the studied area. Many studies have focused on the use of different tree bark species as biomonitor. However, in some studies only pine species were investigated to decide whether pine species can be used as a biomonitor for the determination of heavy metals. Results of such studies showed that the barks of the pine trees are good adsorbents of airborne pollutants, including anthropogenic heavy metals. Different authors have reported the atmospheric pollutants bioaccumulation of pine tree species, due to their widespread with evergreen needle normally 3-5 inches haphazardly warped [19, 22], including Turkish red pine (Pinus brutia Ten.) [14]. This study relates to a seasonal study in the city of Ibadan, with the aim to determine the levels of heavy metals using tree barks as indicators of atmospheric trace metal pollution. The metals investigated are $\mathrm{Pb}, \mathrm{Zn}, \mathrm{Cd}, \mathrm{Cu}, \mathrm{Co}$, and $\mathrm{Cr}$ based on their environmental concerns.

\section{Materials and Methods}

2.1. Study Area. Ibadan, located in southwestern Nigeria, is an ancient city categorized by urban sprawl and modernization [24]; it falls within the basement complex of the geological setting of southern Nigeria which lies between latitude $7^{\circ} 15^{\prime} \mathrm{N}-7^{\circ} 30^{\prime}$ and longitude $3^{\circ} 45^{\prime}-4^{\circ} 60^{\prime} \mathrm{E}$ which possesses two seasonal climates (wet and dry) and moderately the same temperatures in a given season of the year. There has been increased industrialization and urbanization in Ibadan, leading to progressively increased discharges of heavy metals into the atmosphere [24]. The samples of tree backs with different bark morphology were collected from 65 locations within Ibadan city (Figure 1) involving seven different species, namely, Terminalia catappa, Azadirachta indica, Gmelina arborea, Mangifera indica, Gliricidia sepium, Prosopis juliflora, and Murraya species. Decision on sampling zones was made after a careful survey of the traffic densities, industrial distribution pattern covering the whole city of Ibadan. The sampling points designated and number of samples collected include industrial zone $\left(\mathrm{INZ}_{1-20}\right)$, high traffic commercial zone $\left(\mathrm{HTZ}_{1-14}\right)$, residential high traffic zone $\left(\mathrm{RHZ}_{1-16}\right)$, and residential low traffic zone $\left(\mathrm{RLZ}_{1-11}\right)$. The university botanical garden $\left(\mathrm{CTZ}_{1-5}\right)$ aided in the uncontaminated reference point (control) being far-flung from traffic flow. The trees that were closer to the highways (about $5 \mathrm{~m}$ ), about same age, were chosen and the barks were cautiously detached with a clean stainless knife at a height of about $1.8-2.0 \mathrm{~m}$ above the ground level $[25,26]$. The samples were collected in duplicates and thereafter mixed to obtain whole sample.

2.2. Experiment. The samples were dried in the oven at a temperature of $60^{\circ} \mathrm{C}$ for 3-4 hours to a constant weight. The dried samples were pulverized to uniform size with a laboratory mill, thoroughly cleaned, and dried after each grinding to circumvent cross contamination. Samples were kept in clean plastic bags until the time analysis. About $2 \mathrm{~g}$ of the powdered sample was weighed accurately into a precleaned, numbered Vitreosil crucible. They were then transported into the muffle furnace and were preashed in the furnace for about 15 minutes at $150^{\circ} \mathrm{C}$ until the fumes vanished and ashed at the temperature of about $450-500^{\circ} \mathrm{C}$ [27]. The cooled ashed samples were then liquefied with $10 \mathrm{~mL}$ of $10 \%$ $\mathrm{HNO}_{3}$ solution and transfer to precleaned, labelled centrifuge tube. The crucible was again rinsed with portions of acid solution to make a total volume of $20 \mathrm{~mL}$ and vortexed for proper mixing. The samples were centrifuged for 30 minutes at $3000 \mathrm{rpm}$ using HERMLE-Z323 Model. The supernatants were decanted into $100 \mathrm{~mL}$ calibrated volumetric flasks, made up to the mark with the acid solution, and evaluated for metal concentrations with the Buck Scientific Model 210 VGP Atomic Absorption Spectrophotometer possessing airacetylene flame (functioned in line with the instrument's guidebook) and calibrated using mixed calibration standard solutions prepared as mandated [14, 28]. Blank solutions were prepared without the samples using the same procedure.

A spike recovery was used to verify the acid digestion procedure used in this study by spiking portions of previously analyzed samples, six samples including one with a high background or low background. These samples were oven-dried at $105^{\circ} \mathrm{C}$, homogenized, and passed through the extraction and analytical steps [29]. The accuracy and validation of method were determined by analyzing spiked samples using the same reagents, apparatus, and method as those used for the samples. Percentage recovery of $\mathrm{Cr}, 94.20 \pm 8.40 \%$; Zinc, $97.10 \pm 8.91 \% ; \mathrm{Pb}, 93.58 \pm 15.87 \%$; Cu, $94.93 \pm 11.50 \%$; Co, $88.40 \pm 4.67 \%$; and Cd, $97.32 \pm 10.29 \%$ was obtained. The final concentrations of the metals measured in the tree bark samples by A.A.S technique are likely to be the corresponding percentages as the true values, since $100 \pm 20 \%$ recovery is acceptable and all the metal concentrations were within the recovery range value [29-31]. The format used for the calculation of $\%$ recovery is as follows: Percent recovery $(\%$ Recovery $)=(A-B) / C \times 100 \%$.

$A$ is concentration of the spiked sample, $B$ is concentration of the unspiked sample, and $C$ is spike added.

\section{Result and Discussion}

The extractable heavy metal concentrations in the seven species of tree barks sampled from four zones (industrial, high traffic commercial and residential high and low traffic zones) in addition to the control samples (botanical garden, University of Ibadan) in Ibadan are presented in Table 1. 
TABLE 1: Summary of results for tree bark metal concentration (mean $\pm \mathrm{SD}, \mathrm{mg} \mathrm{kg}^{-1}$, dry weight) in all zones.

\begin{tabular}{|c|c|c|c|c|c|c|}
\hline Metal & Parameter & Industrial zone & $\begin{array}{l}\text { High traffic } \\
\text { commercial } \\
\text { zone }\end{array}$ & $\begin{array}{c}\text { Residential } \\
\text { high traffic zone }\end{array}$ & $\begin{array}{c}\text { Residential } \\
\text { low traffic zone }\end{array}$ & Control zone \\
\hline $\mathrm{Pb}$ & Mean \pm SD & $3.67 \pm 1.97$ & $9.62 \pm 7.52$ & $6.70 \pm 3.52$ & $5.96 \pm 6.99$ & $3.59 \pm 2.08$ \\
\hline $\mathrm{Cd}$ & Mean \pm SD & $0.10 \pm 0.07$ & $0.10 \pm 0.06$ & $0.06 \pm 0.05$ & $0.10 \pm 0.07$ & $0.14 \pm 0.07$ \\
\hline $\mathrm{Zn}$ & Mean \pm SD & $30.96 \pm 32.05$ & $45.97 \pm 43.88$ & $22.24 \pm 12.93$ & $16.41 \pm 16.73$ & $8.75 \pm 5.39$ \\
\hline $\mathrm{Cu}$ & Mean \pm SD & $7.29 \pm 5.17$ & $7.11 \pm 9.77$ & $6.97 \pm 3.78$ & $6.14 \pm 2.43$ & $6.25 \pm 2.42$ \\
\hline Co & Mean \pm SD & $0.91 \pm 0.58$ & $0.99 \pm 0.49$ & $0.95 \pm 0.27$ & $0.55 \pm 0.26$ & $0.86 \pm 0.33$ \\
\hline $\mathrm{Cr}$ & Mean \pm SD & $2.61 \pm 1.84$ & $3.12 \pm 1.61$ & $3.35 \pm 1.16$ & $2.39 \pm 1.82$ & $2.45 \pm 0.50$ \\
\hline
\end{tabular}

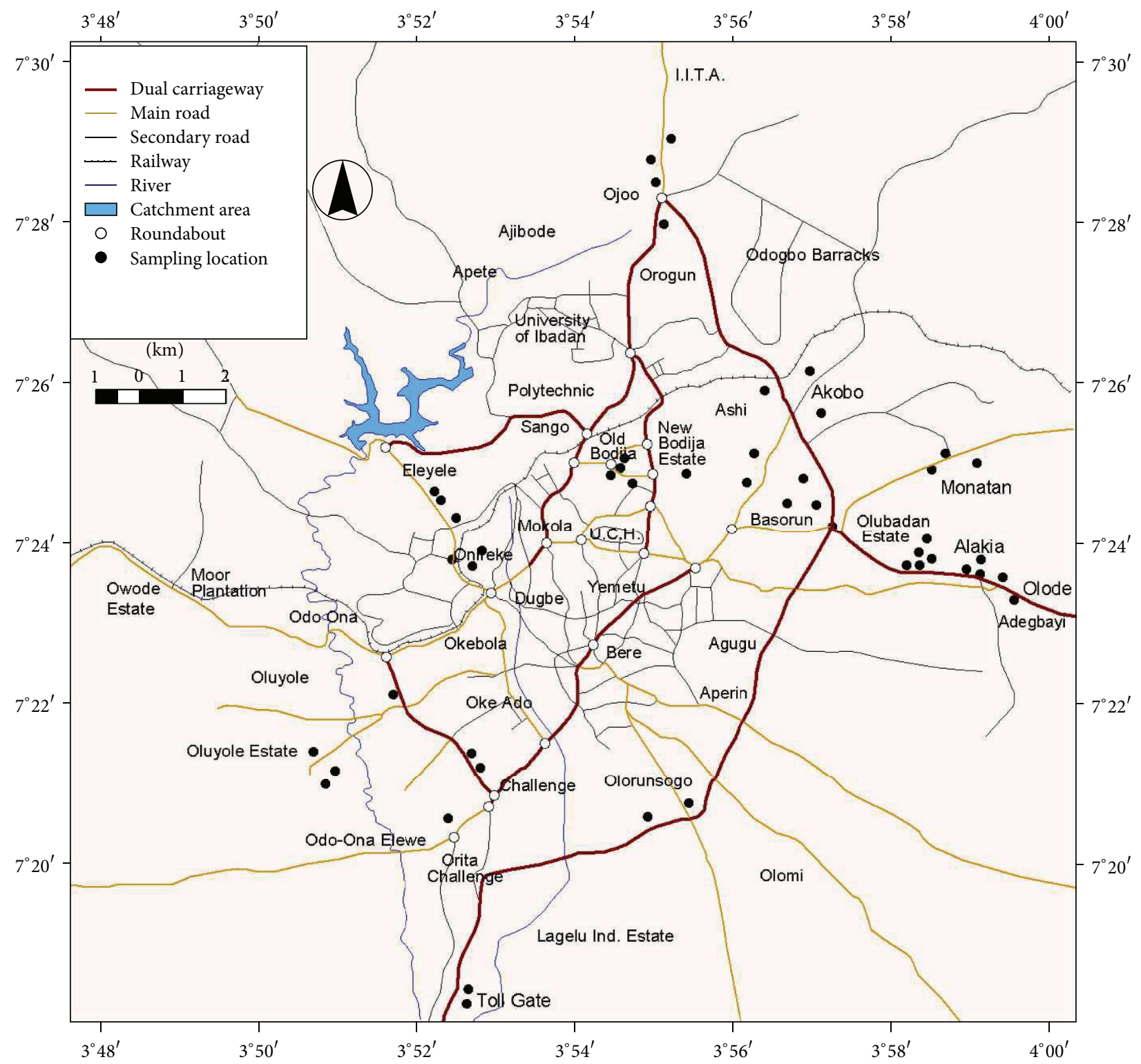

FIGURE 1: Ibadan City map showing the various sampling points.

Various heavy metals accumulation in different plant parts is dependent on the amount of metals present in the ecosystem, and the metal accumulation levels differ within and between species of plants $[9,32]$. Generally, the same trend for metal concentration as found in the control zone was also observed in the industrial zone, residential high traffic zone, and residential low traffic zone that is $\mathrm{Zn}>\mathrm{Pb}>\mathrm{Cu}>\mathrm{Cr}>\mathrm{Co}>$ $\mathrm{Cd}$. However, $\mathrm{Zn}$ showed the highest metal concentration with mean magnitude of $45.97 \pm 43.88 \mathrm{mg} \mathrm{kg}^{-1}$ among all zones (Figures 2(a)-2(f)). Overall mean concentrations 
$\mathrm{Pb}$

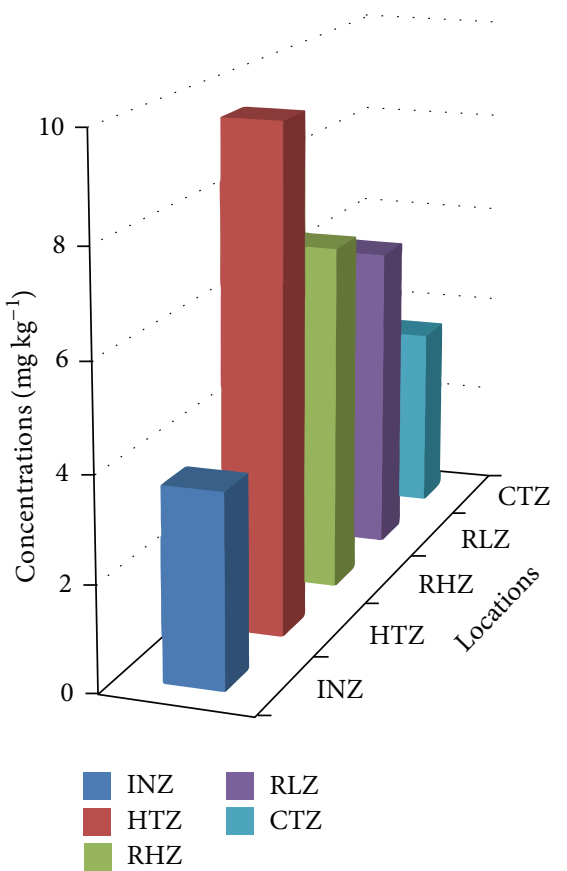

(a)

$\mathrm{Cu}$

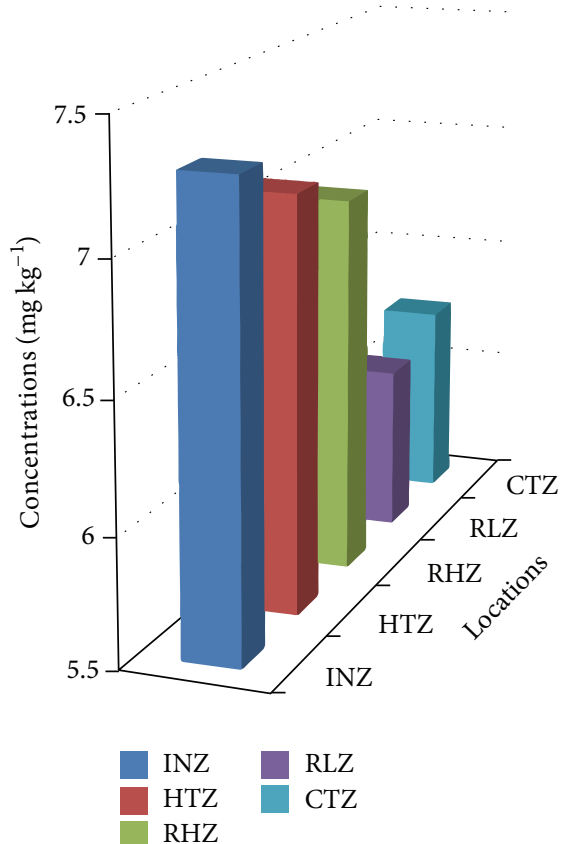

(d)
Cd

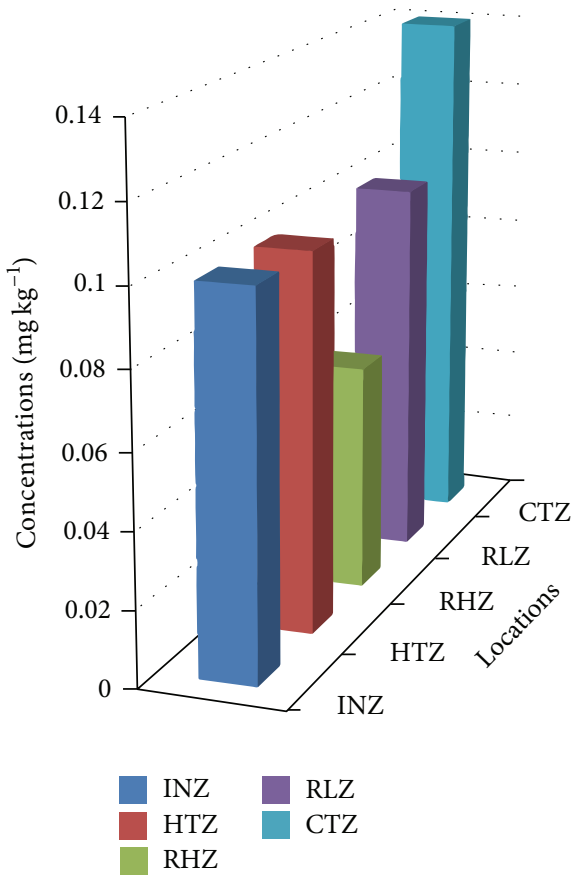

(b)

Co
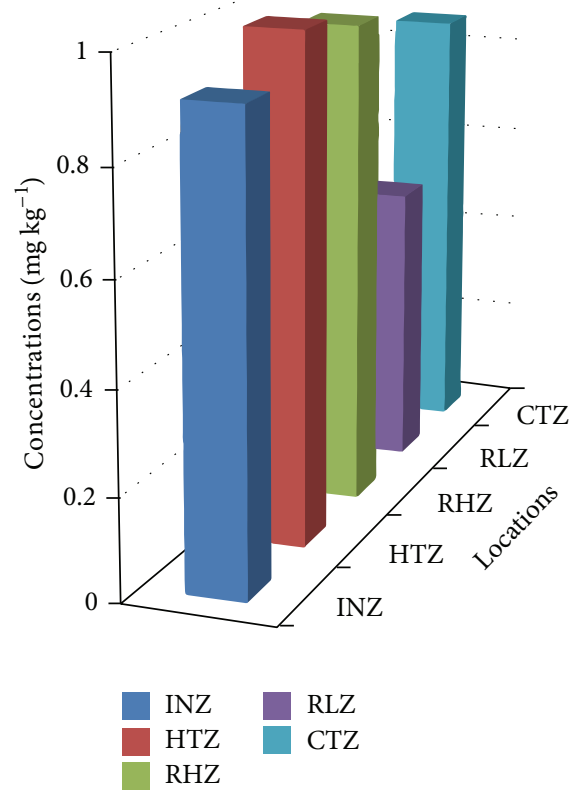

(e)
$\mathrm{Zn}$

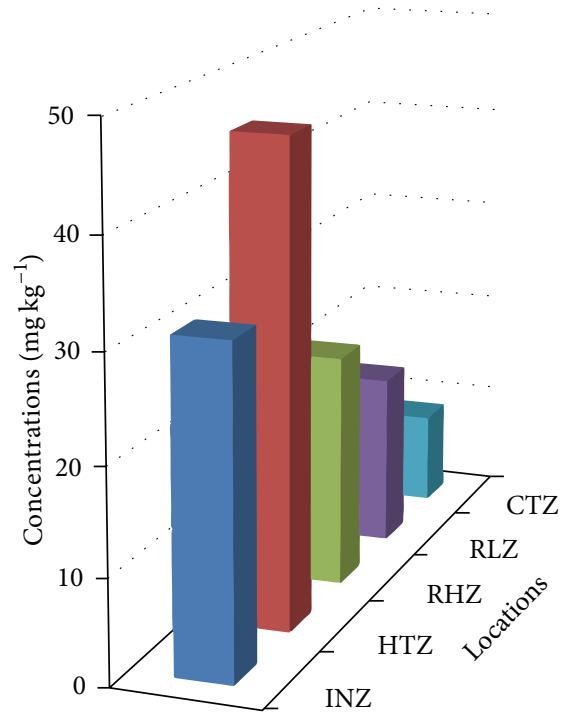

$\begin{array}{ll}\text { INZ } & \text { RLZ } \\ \text { HTZ } & \text { CTZ } \\ \text { RHZ } & \end{array}$

(c)

$\mathrm{Cr}$

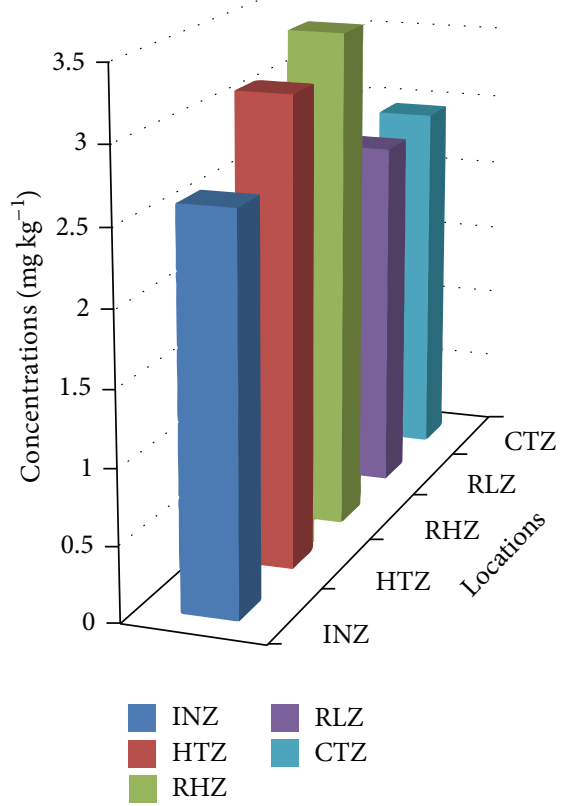

(f)

FIGURE 2: Metal concentrations in tree backs collected from all sampling zones. INZ: industrial zone; HTZ: high traffic commercial zone; RHZ: residential high traffic zone; RLZ: residential low traffic zone; CTZ: control zone.

( $\mathrm{mg} \mathrm{kg}^{-1}$, dry weight) of metals in tree bark samples obtained from this study were found to be $\mathrm{Pb}, 5.99 \pm 5.25$; $\mathrm{Cd}, 0.09 \pm$ 0.07; $\mathrm{Zn}, 27.64 \pm 29.66 ; \mathrm{Cu}, 6.90 \pm 5.54 ; \mathrm{Co}, 0.87 \pm 0.45 ;$ and $\mathrm{Cr}, 2.84 \pm 1.58$ which varied from 0.75 to $29.74,<0.01$ to $0.26,3.70$ to $166.13,1.81$ to $39.12,0.23$ to 2.35 , and $<0.01$ to $8.34 \mathrm{mg} \mathrm{kg}^{-1}$, respectively (Table 2). Abundance of metal concentrations follows the order: $\mathrm{Zn}>\mathrm{Cu}>\mathrm{Pb}>\mathrm{Cr}>\mathrm{Co}>$ $\mathrm{Cd}$. The results indicate the presence of zinc, copper, and lead in high concentrations in samples taken from industrial, high traffic commercial and residential high traffic areas relative to 
TABLE 2: Overall mean metal concentrations ( $\mathrm{mg} \mathrm{kg}^{-1}$, dry weight) in tree bark samples.

\begin{tabular}{lcccccc}
\hline Parameters & $\mathrm{Pb}$ & $\mathrm{Cd}$ & $\mathrm{Zn}$ & $\mathrm{Cu}$ & $\mathrm{Co}$ & $\mathrm{Cr}$ \\
\hline Total & 389.06 & 5.99 & 1796.89 & 448.47 & 56.64 & 184.81 \\
Mean $\pm \mathrm{SD}$ & $5.99 \pm 5.25$ & $0.09 \pm 0.07$ & $27.64 \pm 29.66$ & $6.90 \pm 5.54$ & $0.87 \pm 0.45$ & $2.84 \pm 1.58$ \\
Range & $75-29.74$ & $<0.01-0.26$ & $3.70-166.13$ & $1.81-39.12$ & $0.23-2.35$ & $<0.01-8.34$ \\
\hline
\end{tabular}

residential low traffic and control areas. The concentrations of the heavy metal investigated in this study when compared with metal levels reported by Mleczek et al. [33] revealed that the concentrations obtained in this study were higher for metals like $\mathrm{Pb}, \mathrm{Zn}, \mathrm{Cu}$, and $\mathrm{Cr}$ while the concentrations of $\mathrm{Co}$ and $\mathrm{Cd}$ were lower than those reported in another study; this could be due to the addition of these metals in trace amount in Nigeria petrol as a means of enhancing the octane number of gasoline $[34,35]$.

The results for the metal concentrations showed a marked variation for samples obtained from the industrial zone, Opposite Procter \& Gamble Limited $\left(\mathrm{INZ}_{5}\right)$; high traffic commercial zone, Iwo Roundabout $\left(\mathrm{HTZ}_{13}\right)$; residential high traffic zone, Opposite Coca-Cola Mini Depot $\left(\mathrm{RHZ}_{1}\right)$; and residential low traffic zone, Adeyi Avenue, Old Bodija $\left(\mathrm{RLZ}_{3}\right)$; this generally has the highest value of metal levels. Zinc concentration varied widely in all zones with the residential low traffic zone having the lowest level $16.41 \mathrm{mg} \mathrm{kg}^{-1}$ and the highly trafficked commercial zone possessing the highest level with mean value of $45.97 \mathrm{mg} \mathrm{kg}^{-1}$. The highest concentration of $\mathrm{Zn}\left(166.16 \mathrm{mg} \mathrm{kg}^{-1}\right)$ was observed in the sample collected at Iwo Road Roundabout (Alakia axis) $\left(\mathrm{HTZ}_{14}\right)$ within high traffic commercial zone. The results showed that there is a significant difference in the zinc concentration at $\rho<0.05$ among the zones. However, no significant difference was observed in the zinc concentration of high traffic commercial zone as compared to industrial zone. This indication connotes emission and tyre wear from motor vehicle pointers as a source of the environmental zinc contamination. Also, zinc could be added to the environment during industrial activities like engine wear, waste combustion, exhaust emission, and the use of sewage sludge from industrial areas as fertilizer. $\mathrm{Zn}$ promotes growth and development in the human body but its excessiveness may be an indication of metal poisoning and growth impedance [36].

The concentration of lead in samples obtained from high traffic commercial, residential high traffic, and residential low traffic zones varied slightly with average concentrations of $9.62,6.70$, and $5.96 \mathrm{mg} \mathrm{kg}^{-1}$, respectively. However, possible cradles of metal contaminants in the environment are a crucial part of environmental pollution studies. The chief source of lead $(\mathrm{Pb})$ is the use of leaded gasoline in the 20th century [37-40], which inevitably brings about lead pollutant in the ecosystem. Lead content of Nigeria petrol [0.6-0.8 $\left.\mathrm{g} \mathrm{L}^{-1}\right]$ ranks among the world highest content [41]. Concentrations of lead reported in other studies showed higher values than that obtained in this study except for lead concentration reported by [29, 33, 42, 43]. Human exposure to lead brings about reproductive dysfunction that exhibits biochemical-morphological features including decreased sperm quality, disorganized epithelia, and altered sperm morphology [44]. The analysis of variance showed no significant difference between the levels of copper in all zones at $\rho>0.05$. Copper as a crucial micronutrient is essential for bone growth and formation, neurologic systems, and nervous systems myelin sheaths [45]. The high level (39.12 $\mathrm{mg} \mathrm{kg}^{-1}$ ) of copper concentration in samples sampled from Aworawo along Ojoo road $\left(\mathrm{HTZ}_{9}\right)$, high traffic commercial zones, could result from various human activities. Close look at the results of copper level in residential high and low traffic zones suggests common source. Increased levels could lead to cirrhosis, rheumatoid arthritis, malnutrition, irregular hair growth and depigmentation, fur, growth impairment and reproductive performance, failure of the heart, and disturbances in gastrointestinal systems [44].

Mean concentration of cobalt in the zones was found to follow the trend: high traffic commercial > residential high traffic $>$ industrial $>$ control $>$ residential low traffic (Figures 2(a)-2(f)), with ranges. There is no significant difference observed for the level of cobalt in all investigated zones at $\rho>0.05$. The highest cobalt concentration was found in the Mangifera indica sample from behind Sumal Foods (chewing gum) ( $\left.\mathrm{INZ}_{3}\right)$, industrial zone. Chromium levels were largely low in the study (Figures 2(a)-2(f)), and the residential low traffic zone posed the lowest level of chromium, which could be attributed to natural sources. In various zones, chromium pollution could be due to automobile engine and body erosion, yellow lead chromate paint for road pattern, and few steel and glass industry activities [4648]. Chromium is known as a ubiquitous pollutant from the industrial and environmental activities, also a known human carcinogen, with specificity in cancer of the lungs $[49,50]$. There is no definite gradient in the concentration of cadmium present in the investigated zones. The residential low traffic zone gave $0.10 \mathrm{mg} \mathrm{kg}^{-1}$ and the lowest mean level of cadmium (Cd) was found in residential high traffic zone $\left(0.06 \mathrm{mg} \mathrm{kg}^{-1}\right)$ ranging from 0.01 to $0.15 \mathrm{mg} \mathrm{kg}^{-1}$. The slight increase in the mean level of cadmium in the control zone $\left(0.14 \mathrm{mg} \mathrm{kg}^{-1}\right)$, with the highest concentration found in the Gmelina arborea species $\left(0.25 \mathrm{mg} \mathrm{kg}^{-1}\right)$, could be linked to the use of phosphate fertilizer which has cadmium as a trace element for growing crops. When cadmium is accumulated above the recommended threshold limit, it brings about liver acute and chronic poisoning and also the replacement of calcium within bone matrix of young children [44]; it inhibits increased oxidative stress resulting in the damage of membrane and membrane-enzymes bound losses [51]. 
TABLE 3: Correlation coefficient among metals in tree bark samples from all zones (bold correlations are significant at $\rho<0.05$ ).

\begin{tabular}{ccccccc}
\hline & $\mathrm{Pb}$ & $\mathrm{Cd}$ & $\mathrm{Zn}$ & $\mathrm{Cu}$ & $\mathrm{Co}$ & $\mathrm{Cr}$ \\
\hline $\mathrm{Pb}$ & 1 & & & & & \\
$\mathrm{Cd}$ & $\mathbf{0 . 4 0}$ & 1 & & & & \\
$\mathrm{Zn}$ & $\mathbf{0 . 7 0}$ & 0.31 & 1 & & & \\
$\mathrm{Cu}$ & 0.27 & $\mathbf{0 . 5 0}$ & $\mathbf{0 . 7 9}$ & 1 & & \\
$\mathrm{Co}$ & 0.24 & 0.20 & $\mathbf{0 . 5 4}$ & $\mathbf{0 . 7 7}$ & 1 & \\
$\mathrm{Cr}$ & $\mathbf{0 . 6 7}$ & 0.24 & $\mathbf{0 . 5 5}$ & $\mathbf{0 . 6 3}$ & $\mathbf{0 . 6 9}$ & 1 \\
\hline
\end{tabular}

3.1. Correlation Matrix. A coefficient matrix among $\mathrm{Pb}$, $\mathrm{Cd}, \mathrm{Zn}, \mathrm{Cu}, \mathrm{Co}$, and $\mathrm{Cr}$ concentrations in samples from the studied locations are presented in Table 3. The results showed that the elements investigated in this study are highly correlated with one another, suggesting common source and other possible uncommon sources of metal fallout. There is relatively high correlations amongst metals such as $\mathrm{Zn}$ and $\mathrm{Cu}$ and $\mathrm{Co}$ and $\mathrm{Cu}$. Positive moderate correlation coefficient was observed between $\mathrm{Pb}$ and $\mathrm{Zn}$ and $\mathrm{Zn}$ and Co. The high correlation found between $\mathrm{Pb}$ and $\mathrm{Zn}$ and $\mathrm{Zn}$ and $\mathrm{Cu}$ suggests a common source and other possible well-mixed constituents initiating from different sources. Positive moderate correlation coefficient was also observed between $\mathrm{Cr}$ versus $\mathrm{Pb}$ and $\mathrm{Zn}$ and $\mathrm{Cr}$ versus $\mathrm{Cu}$ and $\mathrm{Co}$. $\mathrm{Zn}$ level in all the zones was seen to be in high concentration followed by $\mathrm{Cu}$ and $\mathrm{Pb}$. High values of $\mathrm{Cu}$ and $\mathrm{Zn}$ obtained indicate that emission and tyre wear from motor vehicle as a source of the environmental zinc contamination; high level of copper could come from the fabrication of brass alloy, brake linings, and electrical and mechanical working while lead could be the use of leaded gasoline in the Nigeria petrol. This is because lead additives in the form of tetraethyl lead (TEL $\left.\left[\mathrm{Pb}\left(\mathrm{C}_{2} \mathrm{H}_{5}\right)_{4}\right]\right)$ are added to gasoline as the cheapest means of boasting the octane number of Nigeria petrol and zinc in the form of organometallic compounds such as zinc dialkyl dithiophosphate (ZDDP), lubricating oils, and tyres $[46,52,53]$.

\section{Conclusion}

The results of this survey demonstrate the suitability of Terminalia catappa, Azadirachta indica, Gmelina arborea, Mangifera indica, Prosopis juliflora, and Murraya species, and Gliricidia sepium bark species as potential bioindicators for $\mathrm{Cu}, \mathrm{Pb}, \mathrm{Zn}, \mathrm{Cr}$, and possibly $\mathrm{Co}$ and $\mathrm{Cd}$ as well as the pointers of some degree of temporal heavy metals contamination. The levels of the metals were higher in bark samples from highly trafficked commercial zone than in other zones. The deviation in metal concentrations amongst the studied sites could be due to various anthropogenic activities. With respect to the high contribution factors of $\mathrm{Zn}, \mathrm{Cu}$, and $\mathrm{Pb}$ to the potential ecological risk of the area, thorough study should be piloted to determine the actual route of the metals entry to the environment. It is imperative that the environmental trace metal levels be constantly examined to diagnose the state and trend of environmental atmospheric pollution. Further monitoring of plant barks species as well as the surrounding lower epiphytes, higher epiphytes, and vascular plants is needed in order to determine whether any temporal trends exist in metal concentration among biological indicators. Potential risk assessment of these heavy metals to crops, animals, and humans in the area is recommended. Further, farming activities within the diameter of $15-10 \mathrm{Km}$ of the vicinity of the industries and high human activities should be discouraged as there will be every possibility of heavy metals uptake by planted crops, which will in turn reach up the food chain and finally to humans. Furthermore, interspecies variation of heavy metal concentrations in plants barks is also recommended.

\section{Conflict of Interests}

Regarding the publication of this paper, the authors declare no conflict of interests.

\section{Authors' Contribution}

The authors contributed equally to the achievement of the research.

\section{Acknowledgments}

The authors wish to acknowledge Govan Mbeki Research and Development Centre (GMRDC), University of Fort Hare, and NRF-Sasol Inzalo Fundation, for financial support received. The authors acknowledge Eyitayo Fadipe and Ayoade Foluke who assisted in the sample collection.

\section{References}

[1] T. Abbasi and S. A. Abbasi, "Is the use of renewable energy sources an answer to the problems of global warming and pollution?" Critical Reviews in Environmental Science and Technology, vol. 42, no. 2, pp. 99-154, 2012.

[2] K. Ravindra, R. Sokhi, and R. Van Grieken, "Atmospheric polycyclic aromatic hydrocarbons: source attribution, emission factors and regulation," Atmospheric Environment, vol. 42, no. 13, pp. 2895-2921, 2008.

[3] C. Woodford, Air Pollution, 2010, http://www.explainthatstuff .com/air-pollution-introduction.html.

[4] U. Makkonen, H. Hellén, P. Anttila, and M. Ferm, "Size distribution and chemical composition of airborne particles in south-eastern Finland during different seasons and wildfire episodes in 2006," Science of the Total Environment, vol. 408, no. 3, pp. 644-651, 2010.

[5] J. Wang, Z. Hu, Y. Chen, Z. Chen, and S. Xu, "Contamination characteristics and possible sources of PM10 and PM2.5 in different functional areas of Shanghai, China," Atmospheric Environment, vol. 68, pp. 221-229, 2013.

[6] G. Qingjie, D. Jun, X. Yunchuan, W. Qingfei, and Y. Liqiang, "Calculating pollution indices by heavy metals in ecological geochemistry assessment and a case study in parks of Beijin," Journal of China University of Geosciences, vol. 19, no. 3, pp. 230241, 2008.

[7] C. O. Ogunkunle and P. O. Fatoba, "Pollution loads and the ecological risk assessment of soil heavy metals around 
a mega cement factory in Southwest Nigeria," Polish Journal of Environmental Studies, vol. 22, no. 2, pp. 487-493, 2013.

[8] H. A. Sani, A. I. Tsafe, B. U. Bagudo, and A. U. Itodo, "Toxic metals uptake by spinach (Spinacea oleracea) and lettuce (Lactuca sativa) cultivated in sokoto: a comparative study," Pakistan Journal of Nutrition, vol. 10, no. 6, pp. 572-576, 2011.

[9] D. Satpathy and M. V. Reddy, "Phytoextraction of Cd, Pb, Zn, Cu and mn by Indian mustard (Brassica juncea L.) grown on loamy soil amended with heavy metal contaminated municipal solid waste compost," Applied Ecology and Environmental Research, vol. 11, no. 4, pp. 661-679, 2013.

[10] D. R. Hashmi, S. Ismail, and G. H. Shaikh, "Assessment of the level of trace metals in commonly edible vegetables locally available in the markets of Karachi city," Pakistan Journal of Botany, vol. 39, no. 3, pp. 747-751, 2007.

[11] G. N. Lion and J. O. Olowoyo, "Population health risk due to dietary intake of toxic heavy metals from Spinacia oleracea harvested from soils collected in and around Tshwane, South Africa," South African Journal of Botany, vol. 88, pp. 178-182, 2013.

[12] B. A. Anhwange, J. A. Kagbu, E. B. Agbaji, and C. E. Gimba, "Trace metal contents of some common vegetables grown on irrigated farms along the banks of river Benue within Makurdi Metropolis," Electronic Journal of Environmental, Agricultural and Food Chemistry, vol. 8, no. 11, pp. 1150-1155, 2009.

[13] S. Baytak, R. Mert, and A. R. Türker, "Determination of $\mathrm{Cu}(\mathrm{II}), \mathrm{Fe}(\mathrm{III}), \mathrm{Mn}(\mathrm{II})$ and $\mathrm{Zn}(\mathrm{II})$ in various samples after preconcentration with Rhizopus oryzae loaded natural cellulose (almond bark)," International Journal of Environmental Analytical Chemistry, vol. 94, no. 10, pp. 975-987, 2014.

[14] S. Baslar, Y. Dogan, N. Durkan, and H. Bag, "Biomonitoring of zinc and manganese in bark of Turkish red pine of western Anatolia," Journal of Environmental Biology, vol. 30, no. 5, pp. 831-834, 2009.

[15] A. Çelik, A. A. Kartal, A. Akdoğan, and Y. Kaska, "Determining the heavy metal pollution in Denizli (Turkey) by using Robinio pseudo-acacia L.," Environment International, vol. 31, no. 1, pp. 105-112, 2005.

[16] G. Nabulo, H. Oryem Origa, G. W. Nasinyama, and D. Cole, "Assessment of $\mathrm{Zn}, \mathrm{Cu}, \mathrm{Pb}$ and $\mathrm{Ni}$ contamination in wetland soils and plants in the Lake Victoria basin," International Journal of Environmental Science and Technology, vol. 5, no. 1, pp. 65-74, 2008.

[17] B. Wolterbeek, S. Sarmento, and T. Verburg, "Is there a future for biomonitoring of elemental air pollution? A review focused on a larger-scaled health-related (epidemiological) context," Journal of Radioanalytical and Nuclear Chemistry, vol. 286, no. 1, pp. 195-210, 2010.

[18] P. K. Rai, "Environmental magnetic studies of particulates with special reference to biomagnetic monitoring using roadside plant leaves," Atmospheric Environment, vol. 72, pp. 113-129, 2013.

[19] B. Kord, A. Mataji, and S. Babaie, "Pine (Pinus Eldarica Medw.) needles as indicator for heavy metals pollution," International Journal of Environmental Science and Technology, vol. 7, no. 1, pp. 79-84, 2010.

[20] I. Rodríguez-Germade, K. J. Mohamed, D. Rey, B. Rubio, and Á. García, "The influence of weather and climate on the reliability of magnetic properties of tree leaves as proxies for air pollution monitoring," Science of the Total Environment, vol. 468-469, pp. 892-902, 2014.
[21] L. Mulligan, An assessment of epiphytic lichens, lichen diversity and environmental quality in the semi-natural woodlands of Knocksink Wood Nature Reserve, Enniskerry, County Wicklow [Ph.D. thesis], Dublin Institute of Technology, 2009.

[22] B. Kord and B. Kord, "Heavy metal levels in pine (Pinus eldarica Medw.) tree barks as indicators of atmospheric pollution," BioResources, vol. 6, no. 2, pp. 927-935, 2011.

[23] L. E. Beramendi-Orosco, M. L. Rodriguez-Estrada, O. MortonBermea, F. M. Romero, G. Gonzalez-Hernandez, and E. Hernandez-Alvarez, "Correlations between metals in tree-rings of Prosopis julifora as indicators of sources of heavy metal contamination," Applied Geochemistry, vol. 39, pp. 78-84, 2013.

[24] D. G. Shendell and G. R. E. E. Ana, "Promoting environmental public health in rapidly urbanizing areas of less-developed countries in Africa: a collaborative interdisciplinary training in Ibadan, Nigeria," Journal of Environmental Health, vol. 74, no. 1, pp. 26-35, 2011.

[25] M. Zhiyanski, M. Sokolovska, J. Bech, A. Clouvas, I. Penev, and V. Badulin, "Cesium-137 contamination of oak (Quercus petrae Liebl.) from sub-mediterranean zone in South Bulgaria," Journal of Environmental Radioactivity, vol. 101, no. 10, pp. 864-868, 2010.

[26] I. Suchara, P. Rulík, J. Hůlka, and H. Pilátová, "Retrospective determination of ${ }^{137}$ Cs specific activity distribution in spruce bark and bark aggregated transfer factor in forests on the scale of the Czech Republic ten years after the Chernobyl accident," Science of the Total Environment, vol. 409, no. 10, pp. 1927-1934, 2011.

[27] T. Sawidis, J. Breuste, M. Mitrovic, P. Pavlovic, and K. Tsigaridas, "Trees as bioindicator of heavy metal pollution in three European cities," Environmental Pollution, vol. 159, no. 12, pp. 35603570, 2011.

[28] S. Leshe and M. Tessema, "Determination of levels of essential and toxic heavy metals in lentil (lens culinaris medik) by flame atomic absorption spectroscopy," African Journal of Chemical Education, vol. 4, no. 4, pp. 16-34, 2014.

[29] F. G. Fujiwara, D. R. Gómez, L. Dawidowski, P. Perelman, and A. Faggi, "Metals associated with airborne particulate matter in road dust and tree bark collected in a megacity (Buenos Aires, Argentina)," Ecological Indicators, vol. 11, no. 2, pp. 240-247, 2011.

[30] P. C. Ogbonna, C. Odukaesieme, and J. A. Teixeira da Silva, "Distribution of heavy metals in soil and accumulation in plants at an agricultural area of Umudike, Nigeria," Chemistry and Ecology, vol. 29, no. 7, pp. 595-603, 2013.

[31] A. I. Ajai, S. S. Ochigbo, Z. Abdullahi, and P. I. Anigboro, "Determination of trace metals and essential minerals in selected fruit juices in Minna, Nigeria," International Journal of Food Science, vol. 2014, Article ID 462931, 5 pages, 2014.

[32] A. R. Ipeaiyeda and M. Dawodu, "Assessment of toxic metal pollution in soil, leaves and tree barks: bio-indicators of atmospheric particulate deposition within a University community in Nigeria," AES Bioflux, vol. 6, no. 2, pp. 101-110, 2014.

[33] M. Mleczek, I. Rissmann, P. Rutkowski, Z. Kaczmarek, and P. Golinski, "Accumulation of selected heavy metals by different genotypes of Salix," Environmental and Experimental Botany, vol. 66, no. 2, pp. 289-296, 2009.

[34] S. E. Kakulu, "Trace metal concentration in roadside surface soil and tree back: a measurement of local atmospheric pollution in Abuja, Nigeria," Environmental Monitoring and Assessment, vol. 89, no. 3, pp. 233-242, 2003. 
[35] J. G. Speight, The Chemistry and Technology of Petroleum, CRC Press, Taylor \& Francis, Boca Raton, Fla, USA, 5th edition, 2010.

[36] K. B. Singh and S. K. Taneja, "Concentration of $\mathrm{Zn}, \mathrm{Cu}$ and $\mathrm{Mn}$ in vegetables and meat food stuff commonly available in Manipur: a North Eastern state of India," Electronic Journal of Environmental, Agricultural and Food Chemistry, vol. 9, no. 3, pp. 610-616, 2010.

[37] A. E. Kelly, M. K. Reuer, N. F. Goodkin, and E. A. Boyle, "Lead concentrations and isotopes in corals and water near Bermuda, 1780-2000," Earth and Planetary Science Letters, vol. 283, no. 14, pp. 93-100, 2009.

[38] N. Robbins, Z.-F. Zhang, J. Sun, M. E. Ketterer, J. A. Lalumandier, and R. A. Shulze, "Childhood lead exposure and uptake in teeth in the Cleveland area during the era of leaded gasoline," Science of the Total Environment, vol. 408, no. 19, pp. 4118-4127, 2010.

[39] A. Roberts, "Chronology of leaded gasoline/leaded petrol history," LEAD Action News, vol. 12, no. 2, 2011, http://www.lead .org.au/nl.html.

[40] P.-C. Huang, P.-H. Su, H.-Y. Chen et al., "Childhood blood lead levels and intellectual development after ban of leaded gasoline in Taiwan: a 9-year prospective study," Environment International, vol. 40, no. 1, pp. 88-96, 2012.

[41] C. W. Rankin, J. O. Nriagu, J. K. Aggarwal, T. A. Arowolo, K. Adebayo, and A. R. Flegal, "Lead contamination in cocoa and cocoa products: isotopic evidence of global contamination," Environmental Health Perspectives, vol. 113, no. 10, pp. 13441348, 2005.

[42] E. Schelle, B. G. Rawlins, R. M. Lark, R. Webster, I. Staton, and C. W. McLeod, "Mapping aerial metal deposition in metropolitan areas from tree bark: a case study in Sheffield, England," Environmental Pollution, vol. 155, no. 1, pp. 164-173, 2008.

[43] M. Catinon, S. Ayrault, O. Boudouma, J. Asta, M. Tissut, and P. Ravanel, "Atmospheric element deposit on tree barks: the opposite effects of rain and transpiration," Ecological Indicators, vol. 14, no. 1, pp. 170-177, 2012.

[44] K. O. Soetan, C. O. Olaiya, and O. E. Oyewole, "The importance of mineral elements for humans, domestic animals and plants: a review," African Journal of Food Science, vol. 4, no. 5, pp. 200$222,2010$.

[45] J. C. Tan, D. L. Burns, and H. R. Jones, "Severe ataxia, myelopathy, and peripheral neuropathy due to acquired copper deficiency in a patient with history of gastrectomy," Journal of Parenteral and Enteral Nutrition, vol. 30, no. 5, pp. 446-450, 2006.

[46] A. L. Al-Khlaifat and O. A. Al-Khashman, "Atmospheric heavy metal pollution in Aqaba city, Jordan, using Phoenix dactylifera L. leaves," Atmospheric Environment, vol. 41, no. 39, pp. 88918897, 2007.

[47] M. A. Nwachukwu, H. Feng, and J. Alinnor, "Assessment of heavy metal pollution in soil and their implications within and around mechanic villages," International Journal of Environmental Science and Technology, vol. 7, no. 2, pp. 347-358, 2010.

[48] N. M. Karaaslan and M. Yaman, "Determination of Nickel and Chromium in Pinus nigra L., Cedrus Libani, and Cupressus Arizonica leaves to monitor the effects of pollution in Elazig (Turkey)," Instrumentation Science \& Technology, vol. 41, no. 3, pp. 335-348, 2013.

[49] C.-Y. Kuo, R.-H. Wong, J.-Y. Lin, J.-C. Lai, and H. Lee, "Accumulation of chromium and nickel metals in lung tumors from lung cancer patients in Taiwan," Journal of Toxicology and
Environmental Health-Part A: Current Issues, vol. 69, no. 14, pp. 1337-1344, 2006.

[50] I. Koturbash, F. A. Beland, and I. P. Pogribny, "Role of epigenetic events in chemical carcinogenesis-a justification for incorporating epigenetic evaluations in cancer risk assessment," Toxicology Mechanisms and Methods, vol. 21, no. 4, pp. 289-297, 2011.

[51] M. Gałażyn-Sidorczuk, M. M. Brzóska, M. Jurczuk, and J. Moniuszko-Jakoniuk, "Oxidative damage to proteins and DNA in rats exposed to cadmium and/or ethanol," Chemico-Biological Interactions, vol. 180, no. 1, pp. 31-38, 2009.

[52] P. R. Shakya, P. Shrestha, C. S. Tamrakar, and P. K. Bhattarai, "Studies and determination of heavy metals in waste tyres and their impacts on the environment," Pakistan Journal of Analytical and Environmental Chemistry, vol. 7, no. 2, pp. 7076, 2006.

[53] H. Spikes, "Low- and zero-sulphated ash, phosphorus and sulphur anti-wear additives for engine oils," Lubrication Science, vol. 20, no. 2, pp. 103-136, 2008. 

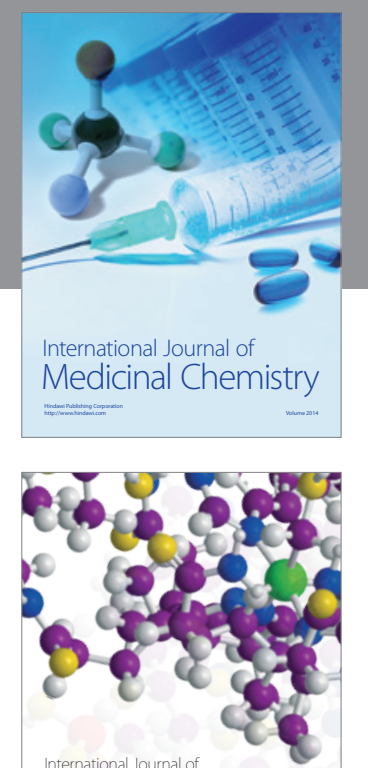

\section{Carbohydrate} Chemistry

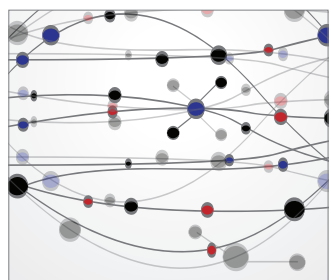

The Scientific World Journal
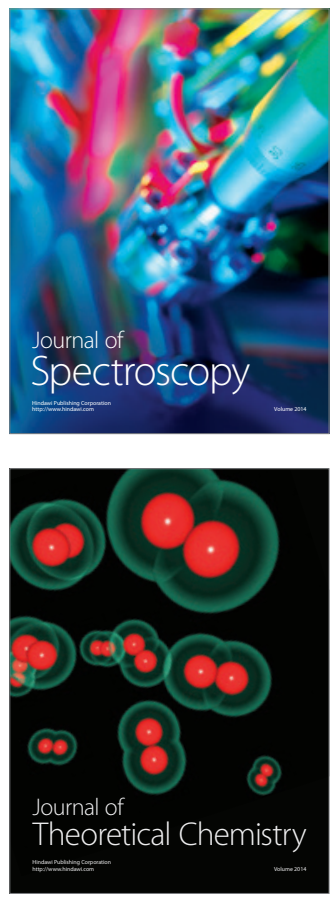
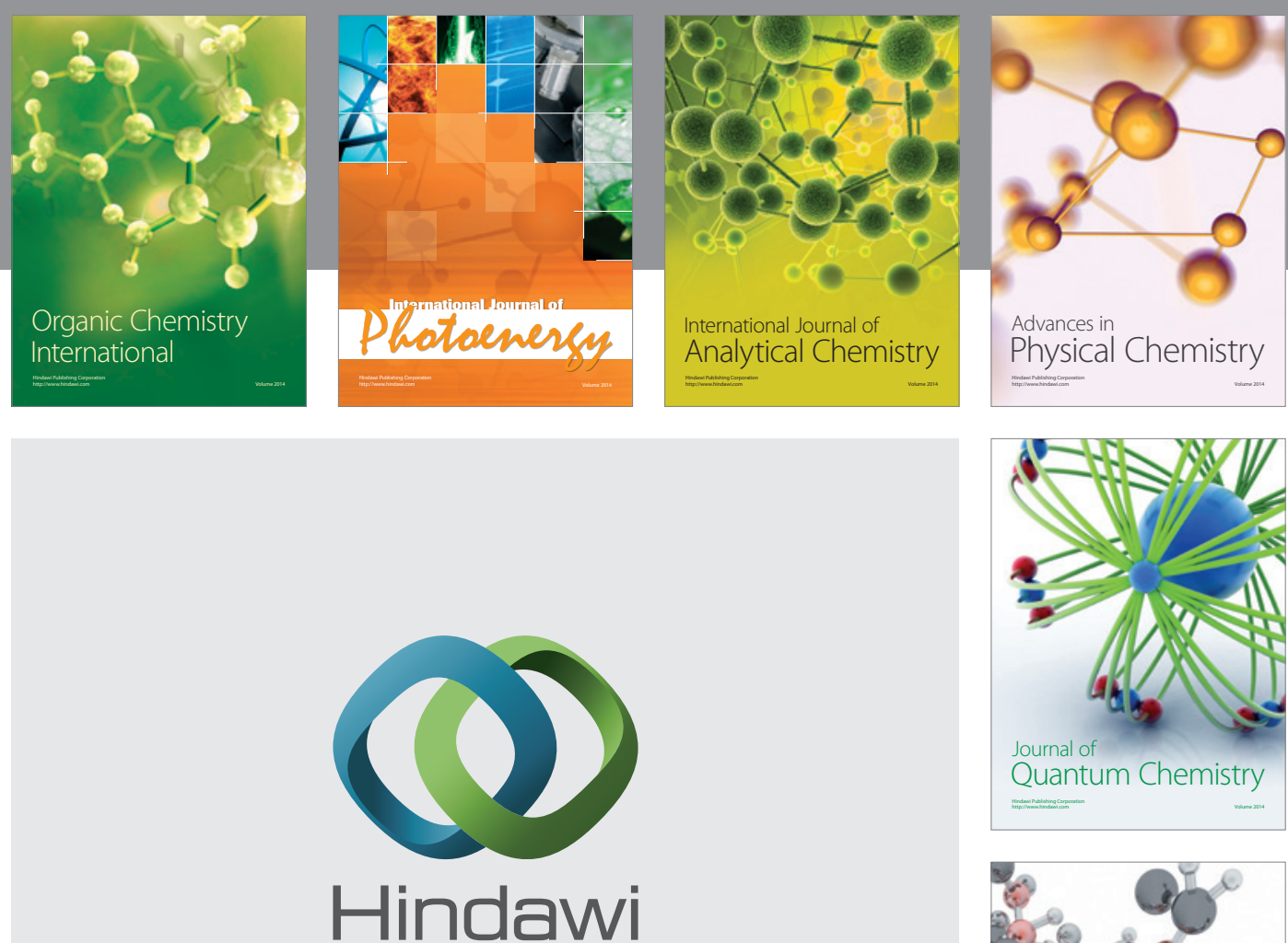

Submit your manuscripts at

http://www.hindawi.com

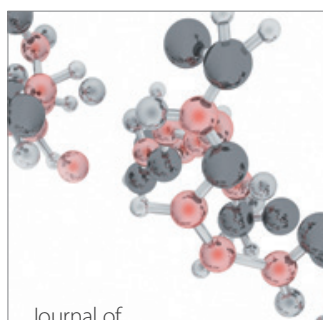

Analytical Methods

in Chemistry

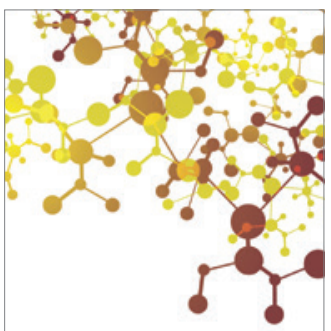

Journal of

Applied Chemistry

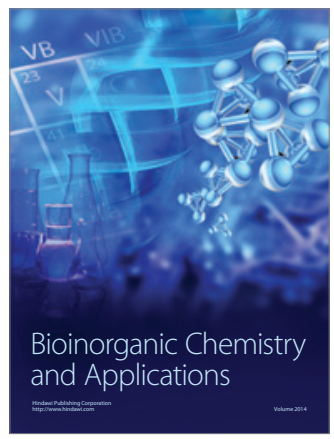

Inorganic Chemistry
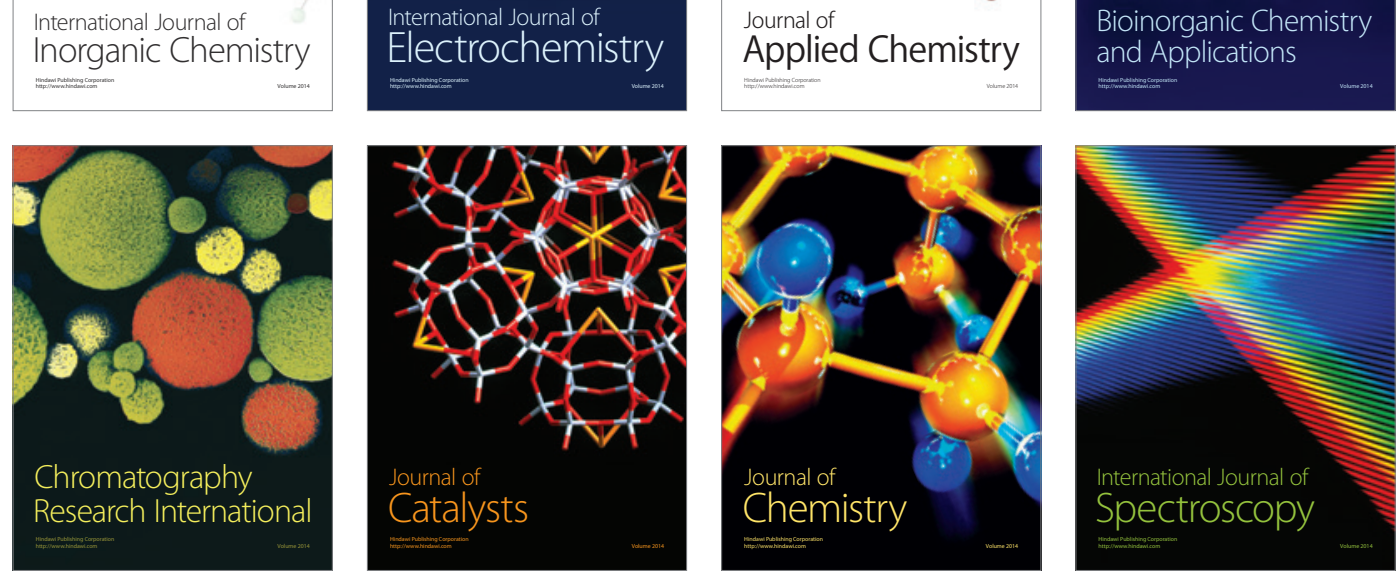